DE DE GRUYTER

OPEN

\title{
THE IMPORTANCE OF WATER TEMPERATURE FLUCTUATIONS IN RELATION TO THE HYDROLOGICAL FACTOR. CASE STUDY - BISTRITA RIVER BASIN (ROMANIA)
}

DOI 10.2478/pesd-2014-0034

PESD, VOL. 8, no. 2, 2014

\author{
Gianina Maria Cojoc ${ }^{1,2}$, Gheorghe Romanescu ${ }^{1}$, Alina Tirnovan ${ }^{1,2}$ \\ Key words: water and air temperature, Bistrita River, climate change, ice jam, \\ Romania
}

\begin{abstract}
The increase in most components of the climate over the past 50 years, including air and water temperature, is a real phenomenon, as attested by the numerous specialized researches according to IPCC (2013). The water temperature is one of the most important climatic components in analyzing the hydrological regime of the Bistrita River (Romania). The thermal regime of the Bistrita River basin and the frost phenomena associated with the risk factor are particularly important and frequently appear in this area. In recent years, under the Siret Water Basin Administration, this parameter was permanently monitored, so we could do an analysis, which shows that the water temperature fluctuations, influenced by air temperature, lead to the emergence of the ice jam phenomenon. The present study aims to analyze the water temperature, as compared to the air temperature, and the effect of these components on the liquid flow regime (the values were recorded at the hydrological stations on the main course of the Bistrita River). The negative effects resulted from the ice jam phenomenon require developing methods of damage prevention and defense. The frost phenomena recorded after the construction of the Bicaz dam are analyzed in this article.
\end{abstract}

\section{Introduction}

The climate is continually changing, and currently is undergoing rapid modifications because of the anthropogenic causes, which overlap the natural causes. In recent years, at the global level, there are many discussions about the serious effects of the economic development evolution on climate change in the

1 Alexandru Ioan Cuza University of Iasi, Faculty of Geography and Geology, nigiana_c@yahoo.com

${ }^{2}$ Siret Water Basin Administration, Bacau, Str.Cuza Voda, 1, 600274, Bacau, Romania 
future. Many scientists are campaigning for the promotion of appropriate technologies in the sustainable development of human society and for the reduction of polluting emissions that lead to global warming (Al Gore, 2006; Gaume et al. 2009; Feyen et al., 2012; IPCC, 2013; Luo et al., 2013). The impact of climate warming is materialized through: changes in temperature, precipitation, and atmospheric dynamics. The climate risk phenomena will gain intensity and a much higher frequency; the hydrological regime of the rivers will be affected etc. The average air temperature rise on Earth is a real phenomenon, as attested by the numerous specialized researches (Sankarasubramanian et al., 2001; Pandi and Mika, 2003; Zhenmei et al., 2008; Zhang et al., 2011) and the effects of global warming could be catastrophic: large area flooding, prolonged droughts, etc.

Our study area is located in a transitional hydro climatic area, from oceanic influences, more humid and with moderate temperature, to continental influences and major thermal and pluvial discontinuities. In the Climate of Romania an analysis of the evolution of air temperature was made (National Meteorological Administration, 2008) and the result was that, during the 20th century, the temperature on Moldova has a growth of 0.6 and $0.8^{\circ} \mathrm{C}$. Because the water temperature is closely linked to the air temperature, it results that the climate change will also affect this parameter.

The water temperature is a very important physical characteristic for rivers, especially if we take into account its influence on aquatic systems. The critical fluctuations that may occur at the level of this parameter, be it of temperature rise over the threshold (maximum accepted water temperature is $30^{\circ} \mathrm{C}$ ) or the low temperatures, lead to the emergence of imbalances in the aquatic systems. The water temperature can be influenced both by human activities, through the discharge of sewage into rivers, and by constructing dams and reservoir (Romanescu, 2005; Webb et al, 2007; Nováky, 2011). The physical-geographical conditions along with the climatic factors from the Bistrita River lead to the occurrence, every winter, of ice forms, which may have different intensities depending on the influence of air temperature over the water temperature. The frequent frost phenomena, which have a significant negative impact on the river Bistrita are the ice jams. The occurrence of these phenomena depends on the climatic conditions, on one hand, and on the other hand on a number of local factors, such as water velocity, water flow rate, the slope of the river, the meanders, the degree of mineralization of underground water, groundwater supply etc. In this study our purpose is to analyze the water temperature fluctuations depending on the influence of air temperature and the negative effects that the frost phenomena have on Bistrita River basin - especially the ice jams. 


\section{Methods}

The water temperature is measured by means of a mercury or alcohol thermometer, with 0.2 degrees subdivisions. In order to obtain accurate values for the temperature the measurement must be done in the stream water and not at the banks level, in the vegetation sectors or in sectors where the water stagnates. In order to measure the water temperature with the thermometer, we have to introduce the mercury reservoir in water and keep it for 5 minutes, after which we do the reading (Zavoianu, 1999). In addition to conventional thermometers, in the last period (starting in 2012), have also been installed temperature sensors, which display the water temperature by means of a dataloger and the data is stored directly on the computer. In the case of classical measurements using the thermometer, measurements are taken twice a day (6 and 17); instead, the sensors record the temperature at more frequent intervals (Siret Water Basin Administration).

The database was made available by the Siret Water Basin Administration, Prognosis, Hydrology and Hydrogeology Bureau. For the present study, we analized information from 7 hydrometric stations on the main course of Bistrita River basin: Carlibaba hydrometric station, Dorna Giumalau hydrometric station, Dorna Arini hydrometric station, Brosteni hydrometric station, Frumosu hydrometric station, Frunzeni hydrometric station and Bacau hydrometric station. The sequence of data has a period of over 50 years.

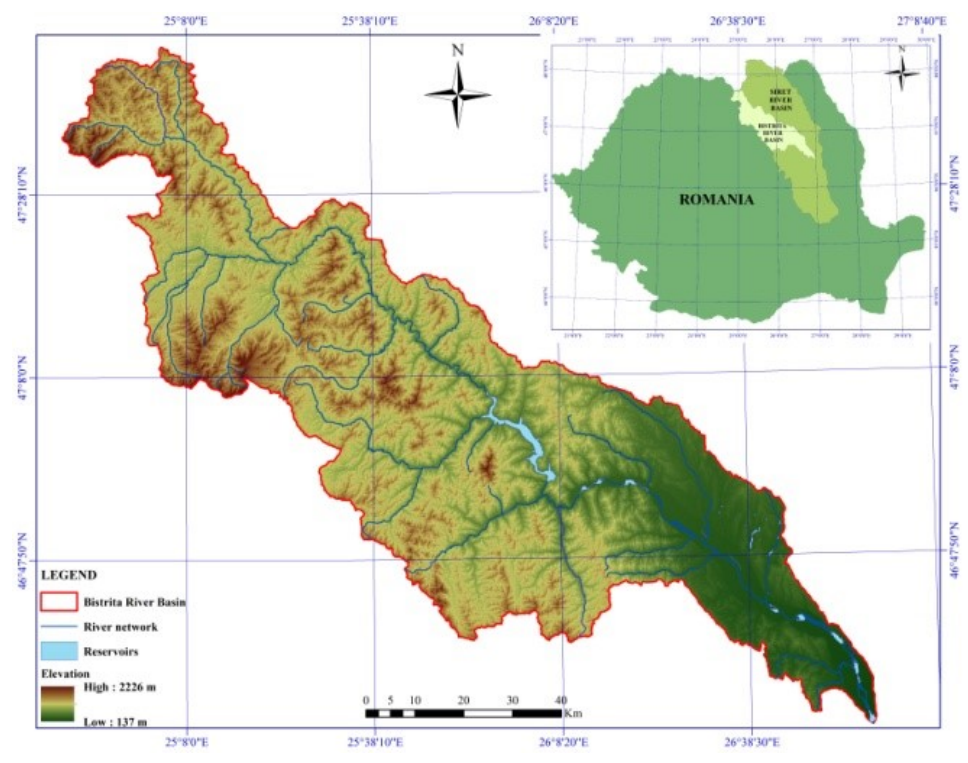

Fig. 1 Geographical position of Bistrita River in Romania 
The Bistrita River springs from Rodnei Mountains and flows into Siret $9 \mathrm{~km}$ downstream Bacau. From the mathematical point of view, the river

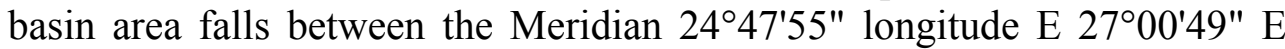
longitude and Parallels of $46^{\circ} 29^{\prime} 33^{\prime \prime} \mathrm{N}$ latitude and $47^{\circ} 44^{\prime} 42^{\prime \prime} \mathrm{N}$ latitude (Fig. 1). The river basin has an elongated like shape NW-SE direction. The hydrographic network includes 193 tributaries (of which: Dorna, Bistricioara, Cracau, Tarcau, Trebes, etc.). The River is passing through the towns Vatra Dornei, Bicaz, Brosteni, Piatra Neamt, Roznov, Buhusi and Bacau. The basin has an area of $7039 \mathrm{~km}^{2}, 283 \mathrm{~km}$ in length, and the average elevation is $919 \mathrm{~m}$ (Donisa, 1968; Siret Water Basin Administration).

\section{Results and discussions}

For the present study, we analyzed the data from 7 hydrometrical stations on the main course of the Bistrita River basin.

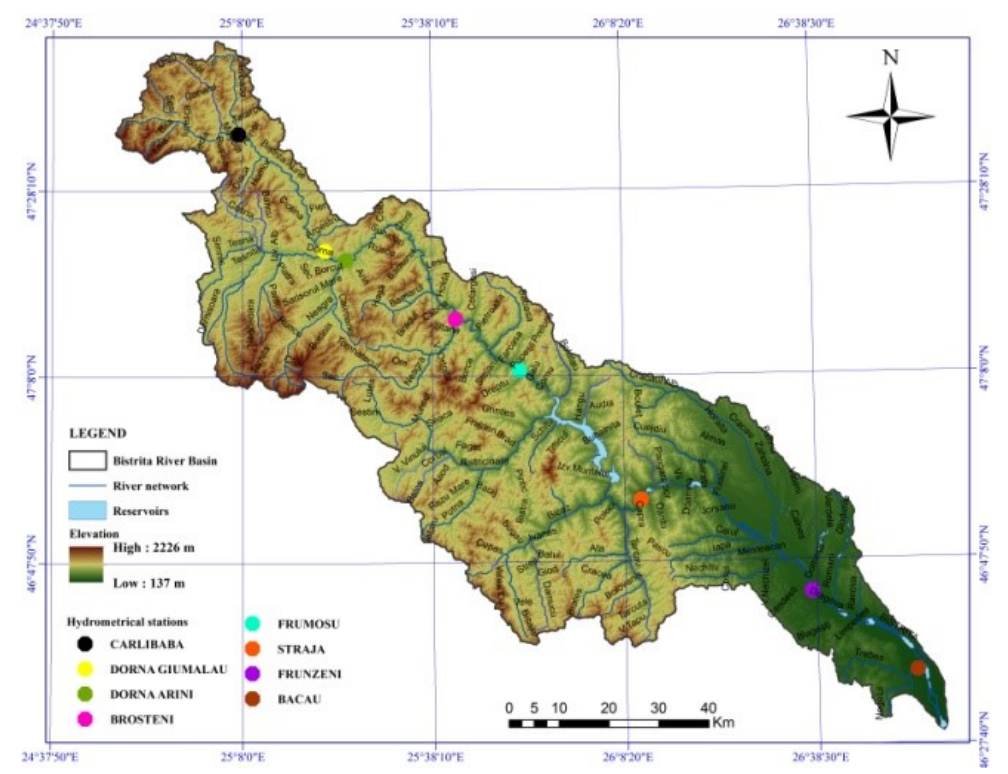

Fig. 2 The localization of the hydrometric stations from the main course of the Bistrita River basin, in Romania

Logically, both water temperature and air temperature are dropping degrees from the source towards the mouth of the Bistrita River. Therefore, the multiannual 
average temperature of the water on Bistrita River has the following values: $6.3^{\circ} \mathrm{C}$ at Carlibaba hydrometric station; $7.1^{\circ} \mathrm{C}$ at Dorna Giumalau hydrometric station; $7.0^{\circ} \mathrm{C}$ at Dorna Arini hydrometric station; $8.2^{\circ} \mathrm{C}$ at Brosteni hydrometric station; $8.4^{\circ} \mathrm{C}$ at Frumosu hydrometric station; $11.0^{\circ} \mathrm{C}$ at Frunzeni hydrometric station and $11.4^{\circ} \mathrm{C}$ at Bacau hydrometric station. Similar to the water temperature decrease is the thermal amplitude decrease having lower values compared to the air temperature.

In the mountain sector the warm season of the year the water temperature is lower than the air temperature, instead, in the cold season appears the reverse situation. In the subcarpathian and plateau areas the air and water temperature values are very similar the first half of the year, from March to July, after which, in August the water temperatures shall be maintained at higher values than air temperature.
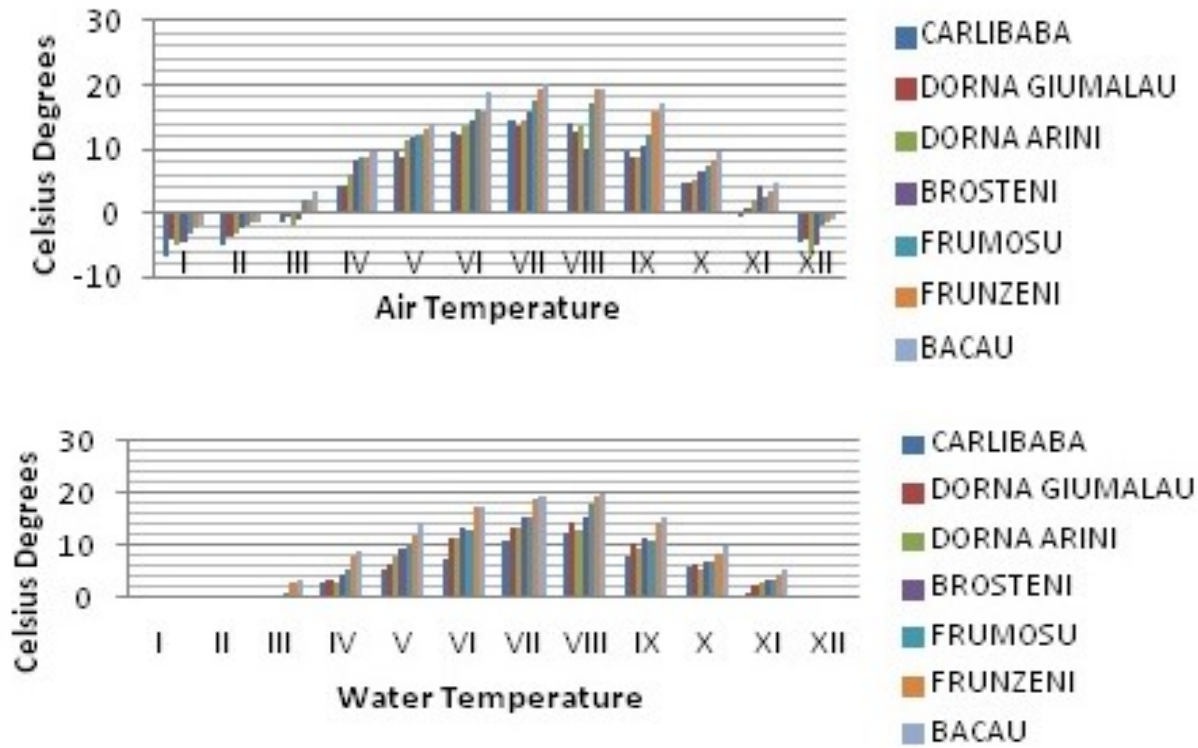

Fig. 3. Comparison between the multiannual average temperatures of water and air at the hydrometrical stations on the Bistrita River at the level of the year 2000

Following a comparative analysis between the multiannual mean values at the level of the year 2000 (Fig. 3), and those from the year 2013 (Fig.4), the conclusion is that the climate change also influences the Bistrita River area, whereas the gradual growth of air temperature and, implicitly, of the water temperature. Another consequence of the climate change is that the frost phenomena start later and disappear earlier. 
During the day, the air temperature increases by the hours 1-2 P.M., and then begins to decline, reaching minimum values towards morning, between the hours 5-6 A.M. during summer time and 7-8 A.M. during winter time. Daily the extreme temperatures of the water, unlike those of the air appear with a delay of a few minutes (about 15 minutes), depending on the water flow.
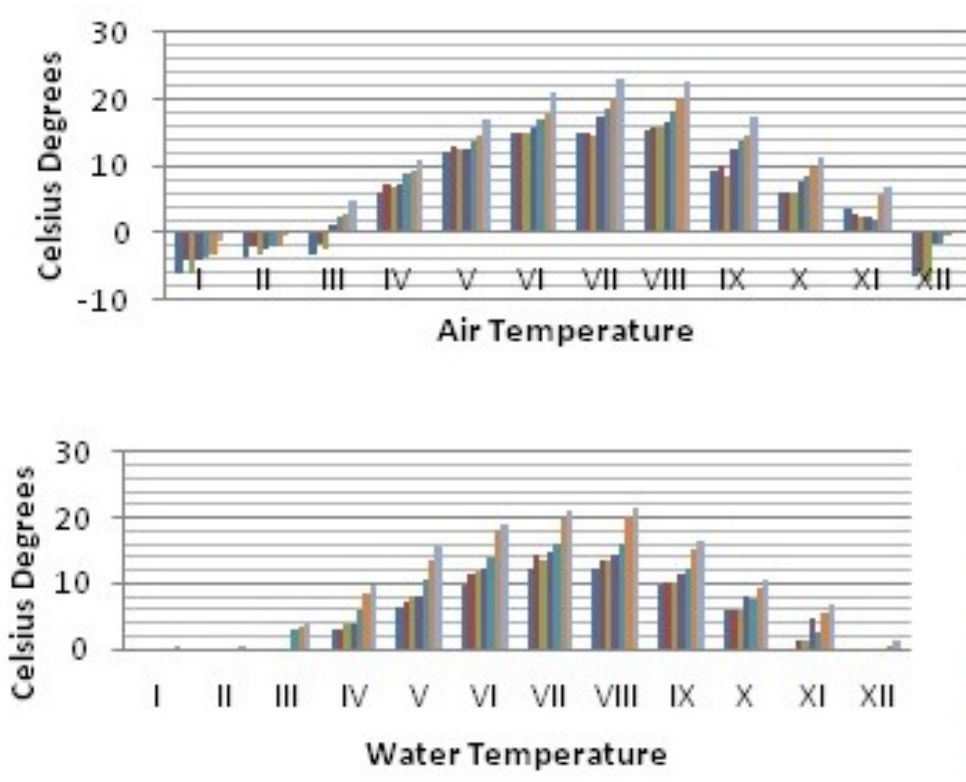

CARLIBABA

DORNA GIUMALAU

DORNA ARINI

BROSTENI

arRUMOSU

ERUNZENI

BACAU

- CARLIBABA

- DORNA GIUMALAU

DORNA ARINI

BROSTENI

aRUMOSU

- FRUNZENI

BACAU

Fig. 4 Comparison between the multiannual average temperatures of water and air at the hydrometrical stations on the Bistrita River at the level of the year 2013

The daily temperature variation graph is similar to that of the air, the exception is that the water temperature values occur later and have slight oscillations. The extreme values of the air temperature are mitigated in the case of water temperature. The same situation can be seen in the case of the monthly changes in water temperature and air. If we analyze the water temperature in the longitudinal profile of the Bistrita River we may notice a decrease in the average temperature of the water, from the mountains sector to the plateau (from the source to the mouth), as a result of the vertical zonality of the rivers' water temperature. In the mountain sector the average multiannual temperature values are $6-7^{\circ} \mathrm{C}$ and as we approach the mouth area temperature increases up to $8.5-9^{\circ} \mathrm{C}$.

The average multiannual temperature variation shows that the lowest temperature values, below $5^{\circ} \mathrm{C}$ can be identified in mountainous areas - the upper sector of the Bistrita River basin - meanwhile the values increase as we move 
towards the plateau, the Bistrita and Siret confluence. From the mountains to the plateau the average gradient of the water temperature increase ranges between 0.5 $1{ }^{\circ} \mathrm{C}$ per 100 meters altitude.

To analyze the variation in time and in space and the thermal regime of the

flowing water we must take into account its dependence on the thermal regime of the air. Besides, the water temperature is also influenced by the volume of water in the river, the characteristics of the flow, the intake of water from aquifers, the exposure to solar radiation, the movement of air masses, the characteristics of the cross sections along the longitudinal profile, the influence of residual water (discharged from industrial targets) etc. If we analyze the cross-section profiles on the Bistrita River, there can be seen a sequence of narrower or wider sectors, depending on the geological structure crossed by the river. In the transverse profile, depending on the velocity, the flow, the roughness of the river, in the narrower sectors the water temperature is homogenous, instead in broader sectors there are small differences, noted that in summer, the water temperature is $1-2^{\circ} \mathrm{C}$ higher at borders than the thalweg, while in winter the situation is opposite.

The maximum water temperatures of rivers usually occur during June and August and vary between $12-22^{\circ} \mathrm{C}$ in the mountain area and $18-30^{\circ} \mathrm{C}$ in the subcarpathian and plateau regions.

The minimum temperatures, which are overlapping the winter frost phenomena occur from December to January, even until March in the mountain sector, being around the $0^{\circ} \mathrm{C}$ or even less so $\left(-2^{\circ} \mathrm{C}\right)$ in the mountain areas where the stream velocity is high and the water cannot freeze at the temperature of $0^{\circ} \mathrm{C}$.

The frost phenomena are installed when the air temperature falls below $0^{\circ} \mathrm{C}$ for smaller or longer periods of time, depending on the liquid flow of rivers and the water velocity. On the narrower or smaller tributaries, the installation of the frost phenomena takes place almost simultaneously with the air temperature recording of the $0^{\circ} \mathrm{C}$ value, since low water volume quickly picks up the negative air temperatures.

Tab.1 The frost period on the Bistrita River

\begin{tabular}{|c|c|c|c|c|c|c|c|c|c|}
\hline \multirow{2}{*}{$\begin{array}{l}\text { Hydrometrical } \\
\text { station }\end{array}$} & \multicolumn{3}{|c|}{ Occurrence date } & \multicolumn{3}{|c|}{ Disappearance date } & \multicolumn{3}{|c|}{ Duration (days) } \\
\hline & Early & Medium & Late & Early & Medium & Late & $\max$ & med & $\min$ \\
\hline Carlibaba & $6 \mathrm{X}$ & $1 \mathrm{XI}$ & $28 \mathrm{XI}$ & $10 \mathrm{III}$ & $25 \mathrm{III}$ & $8 \mathrm{IV}$ & 165 & 132 & 100 \\
\hline D. Giumalau & $28 \mathrm{X}$ & $22 \mathrm{XI}$ & $14 \mathrm{XII}$ & 3 III & $25 \mathrm{III}$ & $6 \mathrm{IV}$ & 135 & 94 & 53 \\
\hline D. Arini & $26 \mathrm{X}$ & $12 \mathrm{XI}$ & $28 \mathrm{XI}$ & $6 \mathrm{III}$ & 19 III & $31 \mathrm{III}$ & 140 & 110 & 80 \\
\hline Brosteni & $2 X$ & $24 X$ & $15 \mathrm{XI}$ & $25 \mathrm{III}$ & $7 \mathrm{IV}$ & $19 \mathrm{IV}$ & 170 & 140 & 110 \\
\hline Frumosu & $28 \mathrm{X}$ & $22 \mathrm{XI}$ & $14 \mathrm{XII}$ & $3 \mathrm{III}$ & $25 \mathrm{III}$ & $6 \mathrm{IV}$ & 135 & 94 & 53 \\
\hline
\end{tabular}

When the air temperature reaches values below $0{ }^{\circ} \mathrm{C}$ the water freezes. The ice has a density of $0.916 \mathrm{~g} / \mathrm{cm}^{3}$, which is why it floats at the water surface thus forming a protective layer, below which the water has a temperature of between 
$0^{\circ} \mathrm{C}$ and $4^{\circ} \mathrm{C}$ (Zavoianu, 1999). Knowing the relation between air temperature and water temperature of the rivers, when the air temperature registers values below $0^{\circ} \mathrm{C}$ changes occur in the water temperature regime also. These phenomena occur in autumn-winter period (even in spring, in the mountain area), a period with previously registered negative air temperatures.

Depending on the degree of development, the frost phenomena, which appear on the Bistriţa River are: ice needles, the first stage; bottom ice (appears especially in the mountain areas - at the bottom of the water due to the low velocity, which allows the installation of ice); the border ice; frazil (snow that does not melt in the water); grease ice (groups of ice needles in the water); unfrosted channel; discontinued ice bridge; continuous ice bridge; water over the ice bridge; unfrosted borders (appears in spring, when the temperature rises and the ice from the borders, being thinner, melts); floes; ice jam (an agglomeration of floes in the narrow sectors of the river or at bridges, which obstruct the runoff and produce overflows and floods) (Surdeanu, 2005; Stefanache, 2007; Dumitra, 2008; Raduly, 2010). The last phenomena constitute a risk factor because of their frequency and magnitude. In recent years, in the upstream sector of Poiana Teiului, such ice jams occur almost annually (with different intensities). These are determined by both natural and anthropogenic factors. Upstream the Izvoru Muntelui Reservoirs, the frost phenomena shall be recorded each year with an average of 75 days, the continuous ice bridge occurs less frequently, with an interval of 4-5 years and an average duration of 35 days. This phenomenon manifests itself almost annually from both natural causes and human-induced causes.

The natural causes are: the persistence of very low temperatures (below $10^{\circ} \mathrm{C}$ ) for a longer period of time, leading to the development of compact ice formations; the intrusion of the warmer air masses from the West (Dorna Depression and Bistrita Depression), that causes the increase in water and air temperature from upstream to downstream and leads to the separation of floes and ice jam formations, with sudden increases in water level upstream; high fluctuations in air temperature from day to night and day by day; the succession in Bistrita River of different slope sectors, the existence of meanders and the narrow cross-sections in certain sectors; the Bistrita Depression in the sector between Borca and Poiana Teiului villages is very narrow; the minor riverbed has a width from 50 to 80 meters and a major riverbed between 300 and $1500 \mathrm{~m}$.

The anthropogenic causes are: the presence of bridges, household annexes; the presence, in the area, of unfinished hydropower constructions; the existence of Izvoru Muntelui accumulation influencing the hydro meteorological phenomena in the area. Depending on the intensity, some ice jams produce increases in levels upstream the dams causing flooding and property damage. In addition, problems arise because of the destructive action of the moving floes. Among these must be 
mentioned: the destruction of bridges, foot bridges, household annexes, fences, houses (sometimes). Following in time an analysis of the frequency and intensity of the ice jams, in the Bistrita river basin, the most significant developments have occurred in the years 1968, 1995, 2003, and in 2007, 2008, 2009 had lower intensities.

The 25-27 February 1968 ice jam. It formed clumps of floes of 40-50 cm, behind which it has accumulated water. The river level has increased to about 250 $\mathrm{cm}$ values over normal situations and remained so for about 10 hours, producing flooding of meadow, of housing and of their annexes.

The December 1995 ice jam. This year there have been ice jams along the Bistrita River up to Poiana Teiului. Agglomerations of ice forms were extended on a $15 \mathrm{~km}$ length and because of the impossibility of the Izvoru Muntelui Reservoir to discharge the ice load levels increased upstream. The Bistrita River levels had fluctuations around the attention quota $(28 \mathrm{~cm}$ over the attention quota).

The December 31, 2002 -January 1, 2003 ice jam was the worst. The length of the built-up ice jam was 13 kilometres upstream Poiana Teiului. The agglomerations of ice thickness was 1-6 m. Houses, household annexes, bridges, foot bridges were destroyed and damaged. It was registered animal mortality. In Poiana Teiului there were 3 human victims.

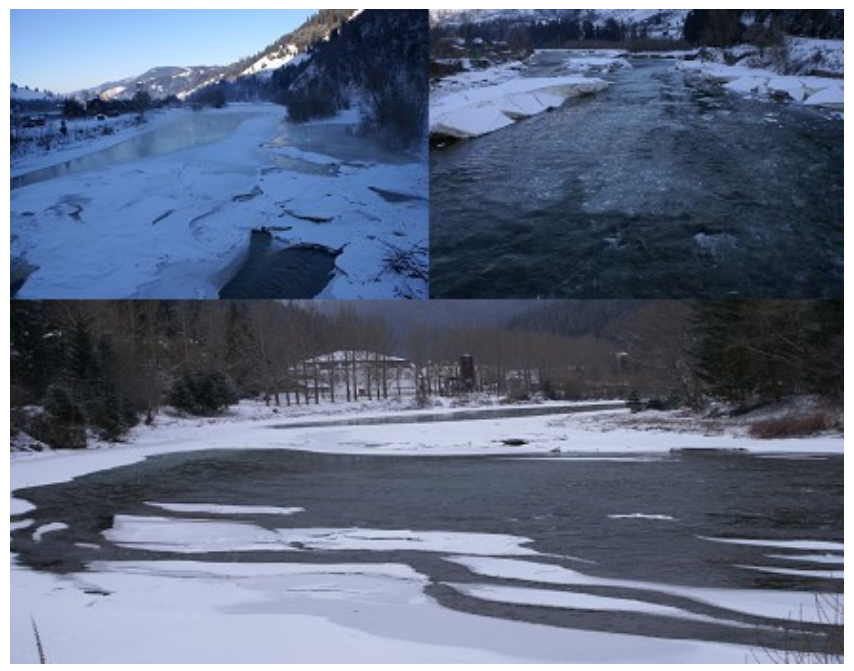

Fig. 5. The manifestation of Bistrita River ice jam phenomenon

The December 2007 to January 2008 ice jam. The river formed clumps of ice, which led to the formation of blockages from the tail of Izvoru Muntelui Reservoir to Farcasa 
locality, in Neamt County, on a distance of $21.1 \mathrm{~km}$ and a thickness of the frozen iceland between 0.2 and $6 \mathrm{~m}$.

The December 2008 to January 2009 ice jam (Fig.6). The low temperatures and flow zof the grease ice at the rate of $50-60 \%$ of the surface water led to the expansion of built-up areas of ice, reaching a length of 21.2 kilometres up to Pintei locality, in the commune of Borca and a thickness of 0.2 and $5 \mathrm{~m}$. Throughout the manifestation of the phenomenon didn't occur special problems, but the water infiltrations in the cellars and courtyards.

The December 2009 to January 2010 ice jam. The negative temperatures from the Bistrita River basin led to the emergence of the grease ice that led to the formation of blockages for a $14.8 \mathrm{~km}$ length from the tail of the Izvoru Muntelui Reservoir to the Vadu Rau Bridge, with thickness between 30-40 cm. There were no reported damages.

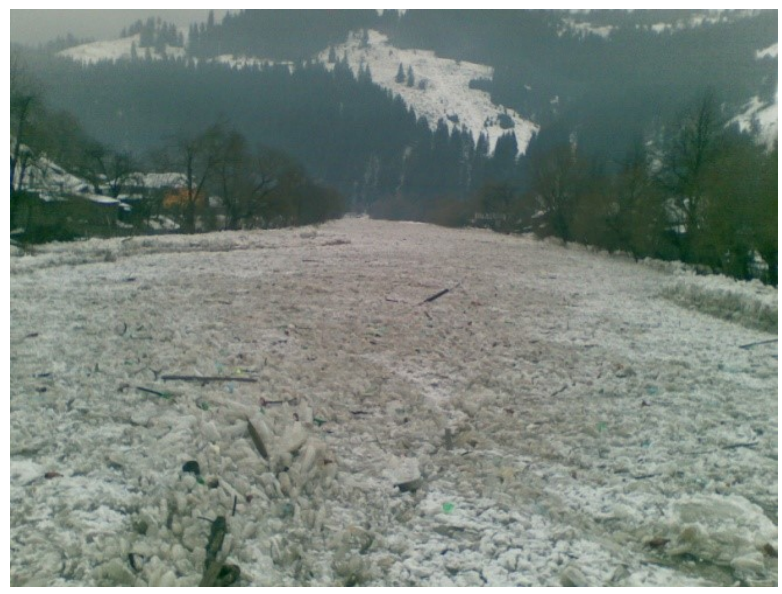

Fig. 6 The manifestation of Bistrita River ice jam phenomenon 2008-2009

Starting from the causes, conditions and evolution, the ice jams can be controlled and prevented by various means. We cannot intervene in the natural causes, as they will keep in the future, but if we refer to the morpho-hydrographic and hydraulic conditions of the riverbeds, here we might intervene with a number of changes. The issue in this case is that such works are costly and can have negative side-effects (for example: ensuring the high velocity increase of the runoff leads to riverbed processes, bank and thalweg erosion etc.).

Most measures are at hand: the removal of obstacles of riverbeds or on the banks (fences, household annexes); proper sizing of bridges and foot bridges; removal of built-up ice jams in order to avoid their development etc. During the evolution of the dangerous ice jams overseeing their permanent evolution is necessary in order to be able to announce and timely take the necessary measures downstream. In the most serious cases people from areas at risk are evacuated. 


\section{Conclusions}

The thermal regime of the Bistrita River basin and the associated frost phenomena represent a risk factor particularly important and frequent in this area. The present study analyzed the water temperature, as compared to the air temperature, and the effect of climate change on the liquid flow regime (the values were recorded at the hydrometrical stations on the main course of the river Bistrița).

The ice jams develop on an annual frequency, sometimes even two or three times a year on the Bistrita River upstream the Izvoru Muntelui Reservoir, on the state of hydro meteorological conditions of the basin. The length of the river on which the ice jams appear reaches up to 25 kilometers, blocking entire sections of the riverbed. The agglomerations of ice thickness reach up to $5-7 \mathrm{~m}$ in critical areas, where the bed is narrow and meandered. The existence of Izvoru Muntelui accumulation makes it difficult to unlock the ice formations, when it has ice bridge in the tail. This phenomenon manifests itself violently when unlocking the ice blocks and leads to flooding with economic, social and human damage. Because of the the very low water flow rate $\left(10-15 \mathrm{~m}^{3} / \mathrm{s}\right)$ during this period, the ice formations cannot float or move and remain blocked on the thalweg.

The most significant developments have occurred in the years 1968, 1995, 2003, and in 2007, 2008, 2009 were less intense. The negative effects of the ice jam phenomenon require developing methods of prevention and reduction. Human intervention for the reduction of the effects of these phenomena is limited because non-structural measures are useful for the short term period; meanwhile structural measures involve some very high costs.

Aknowledgement: This work was supported by strategic grand POSDRU 159/1.5/133391, Project "Doctoral and Post-doctoral programs of excellence for highly qualified human resources training for research in the field of Life sciences, Environment and Earth science" cofinaced by the European Social Fund within the Sectorial Operational Program Human Resources Development 2007-2013 .

\section{References:}

Al Gore. (2006), An Inconvenient Truth: The Planetary Emergency of Global Warming and What We Can Do About It. Rodale Books, New York 325.

Donisa, I. (1968), Geomorfologia văii Bistriței, Editura Academiei, București.

Dumitra, Alina-Daciana (2008), Caracteristicile fenomenelor de îngheț din Depresiunea Almaş-Agrij și Dealurile Clujului și Dejului, Editura Geographia Napocensis, Anul II, nr 2, Cluj Napoca. 
Feyen, L., Dankers, R., Bódis, K., Salamon, P., Barredo, JI. (2012), Fluvial flood risk in Europe in present and future climates. Climate Change 112(1): 47-62.

Gaume, E., Bain, V., Bernardova, P., Newinger, O., Barbuc, M., Bateman, A., Blaškovičová, L., Blöschl, G., Borga, M., Dumitrescu, A., Daliakopoulos, I., Garcia, J., Irimescu, A., Kohnova, S., Soutroulis, A., Marchi, L., Matreata, S., Medina, V., Preciso, E., Sempere-Torres, D., Stancalie, G., Szolgay, J., Tsanig, I., Velasco, D., Viglione, A. (2009), A compilation of data on European flash floods. Journal of Hydrology 367(1-2): 70-78.

Luo Yuzhou, Darren L. Ficklin, Xiaomang Liu, Minghua Zhang (2013), Assessment of climate change impacts on hydrology and water quality with a watershed modeling approach, Science of the Total Environment 450-451 : 72-82.

Nováki, B. (2011), Effects of climate change on daily water temperature in the Hungarian lower Danube River, Riscuri și catastrofe, An X, Volum 9, Nr, 2, Cluj Napoca.

Pandi, G., Mika, I. (2003), River runoff extremes and tendencies: factors of risk likely related to global climate. Riscuri si catastrofe 2: 116-129.

Raduly, D. (2010), Riscurile induse de fenomenele de îngheț pe râurile Târnava Mare, Târnava Mică și Niraj în Subcarpații Transilvaniei și spațiul montan limitrof, Riscuri și Catastrofe, An IX, Volum 8, Nr 1, Cluj Napoca.

Romanescu, G. (2005), Riscul inundaţiilor în amonte de lacul Izvorul Muntelui şi efectul imediat asupra trăsăturilor geomorfologice ale albiei, Riscuri și Catastrofe, Volum IV, Nr 2, Cluj Napoca.

Sankarasubramanian, A., Vogel, RM, Limbrunner, JF. (2001), Climate elasticity of streamflow in the United States. Water Resources Research 37(6): 1771-1781.

Stefanache, Dumitrica (2007), Cercetări privind evoluţia unor fenomene hidrografice periculoase, Rezumatul Tezei de doctorat, Universitatea Tehnică Gheorghe Asachi, Iaşi.

Surdeanu, V., Berindean, N., Olariu, P. (2005), Factorii geografici care determină formarea zăpoarelor în bazinul superior al râului Bistrița, Riscuri și Catastrofe, Volum IV, Nr 2, Cluj Napoca.

Webb, B.W., Nobilis, F. (2007), Long term changes in river temperature and the influence of the climatic and hydrological factors, Hydrological Sciences Journal, 52(1), IAHS Press, UK.

Zhenmei, M., Shaozhong, K., Lu, Z., Ling, T., Xiaolong, S. (2008), Analysis of impacts of climate variability and human activity on streamflow for river basin in arid region of northwest China. Journal of Hydrology 352: 239-249.

Zhang, H., Huang, GH, Wang, D., Zhang, X. (2011), Uncertainty assessment of climate change impacts on the hydrology of small prairie wetlands. Journal of Hydrology 396: 94-103. Doi:10.1016/j.hydrol.2010.10.037.

Zavoianu, I. (1999), Hidrologie, Editura Fundația României de Mâine, București.

ABAS (Administraţia Bazinală de Apă Siret), Arhivă.

*** Clima României, (2008), Editura Academiei Romane, București.

*** https://www.ipcc.ch/report/ 